[VOL. XXIV, NO. 3

\title{
KAMLOOPS V. NIELSEN - GOOD RESULT, UNCLEAR LAW
}

\section{P.S. ELDER*}

Supreme Court of Canada judgments are expected not only to give us brute results - City of Kamloops' appeal dismissed - but to illuminate the law for the future. The result in Kamloops v. Nielsen,' that the city was liable for negligence, does accord with trends in the U.S. ${ }^{2}$ and in England. ${ }^{3}$ Nevertheless, the reasons for judgment are not clear enough to allow a confident assessment of the case's implications. Municipal administrators are, perhaps understandably, quaking in their shoes.

The case involved a home built by Hughes Jr. for his parents. Construction of the foundations did not accord with the approved plans and the defendant city's building inspector issued a "stop work order"4 that the builder ignored. The building inspector reported these facts to Council. ${ }^{5}$ Now Hughes Sr. was a city alderman and after buying the property from his son and receiving official notice of the stop work order, he lobbied to have the order ignored. According to evidence from the city's planning director, Hughes Sr. argued in "Council in Committee" that any defects would be his problem since he was going to own and live in the property.

Nothing further was done to enforce the stop order, nor was any occupancy permit ever issued, in spite of repeated requests by the Hughes. Less than four years after this, the plaintiff purchased the property and one year later the subsidence of the foundations was discovered. He thereupon sued the vendors, Mr. and Mrs. Hughes Sr., for fraudulent misrepresentation, breach of contract and (against only Mr. Hughes $\mathrm{Sr}$.) for negligence in construction. He also sued the city for negligence for failing to enforce the stop work order.

At trial, the defendants were found liable and the damages awarded were apportioned $75 \%$ against Mr. Hughes Sr. (and perhaps Mrs. Hughes) ${ }^{6}$ and $25 \%$ against the city. The city appealed but the decision was upheld by both the B.C. Court of Appeal and the Supreme Court of Canada, in spite of a vigorous dissent in the Supreme Court by McIntyre and Estey JJ.

- Professor of Law in Environmental Design, The University of Calgary. I acknowledge with thanks the financial assistance of The Alberta Law Foundation to study aspects of legal liability for negligent design, construction and inspection. Thanks are also due to Research Assistant Bill Walker, student in the Faculties of Law and Environmental Design, The University of Calgary.

1. [1984] 2 S.C.R. 2.

2. J. Kusler, “Liability as a Dilemma for Local Managers"' (1985) 45 Public Admin. Rev. 118.

3. Dutton v. Bognor Regis Urban District Council [1972] 1 Q.B. 373 (C.A.); Anns v. Merton London Borough Council [1978] A.C. 728; and Dorset Yacht Co. Ltd. v. Home Office [1970] A.C. 1004.

4. There was no specific authority in either the Municipal Act of B.C. (R.S.B.C. 1960, c. 255, as am.) or in the Kamloops by-law for such an order. Section 903 of the by-law referred to the building inspector's power to issue a written notice "to the owner of any property directing him to correct any condition"' in violation of the by-law.

5. Supra n. 1 at 50 (per McIntyre J., in dissent).

6. The trial judge found "both defendants" liable but did not mention Mrs. Hughes Sr. at all in his lamentably short reasons for judgment. 
The Supreme Court of Canada, per Wilson J., applied Lord Wilberforce's analysis in Anns v. Merton London County Council.' The Anns analysis entailed that a public authority could owe a private law duty "over and above, or perhaps alongside" that owed under public law. Whether the public body has a (mere) power to act or a duty to do so was unimportant. The important question was whether the decision complained of was at the policy level, in which case a municipality acting in good faith would not be liable, or at the operational level, in which case the negligent acts of its employees would render the municipality liable. Bylaw enforcement issues (such as the number of inspectors and the frequency of inspections) could be affected by budgetary or efficiency considerations and the rightness or wrongness of this type of decision is not for the courts, but for the ballot box. ${ }^{8}$ So far, so good. But the style and ambiguous, shifting wording of Wilson J.'s reasons for judgment leave us a bit at sea. Let us look at several problems in the majority's formulation of the law. We will see that the majority and the minority seem almost to be talking about different cases, although I believe they can be reconciled.

Before indulging in any serious criticism of the case, however, it should at least be mentioned that several matters are usefully clarified by the Kamloops case. First, the Anns analysis just described is now clearly good law in Canada, although the desirability of this is not unanimously agreed. ${ }^{9}$ Second, the Rivtow case ${ }^{10}$ is distinguished. Apparently that case's refusal to compensate economic loss is not binding when the claim is against a public authority for breach of a private law duty of care arising under a statute when economic loss is the very type the statute is trying to prevent." Also, considerations of contract are present in Rivtow but absent in Kamloops. Third, other issues concerning economic loss are clarified. There is no universal test as to who is entitled to compensation for economic loss. To avoid indeterminate liability to an indeterminate class, Wilson J. suggests a number of possible factors depending on the nature of the case. ${ }^{12}$ Fourth, the limitation period in building negligence cases starts to run, not when the damage is done, but when it is reasonably discoverable. Pirelli ${ }^{13}$ is rejected in favour of Sparham-Souter. ${ }^{14}$

\section{DISAGREEMENT ON THE FACTS}

The main disagreement between the majority and the minority rested on a reading of the evidence. Wilson J. cites testimony of the city's planning director that Hughes Sr. had pleaded in the council chamber with his fellow

7. Supra n. 3.

8. Supran. 1 at 9-10.

9. See J.C. Smith and Peter Burns, "The Good Neighbour on Trial: Good Neighbours Make Bad Law" (1983) 17 U.B.C. Law Rev. 93.

10. Rivtow Marine Ltd. v. Washington Iron Works [1974] S.C.R. 1189.

11. Supra n. 1 at 33.

12. Id. at 35 .

13. Pirelli General Cable Works v. Oscar Faber and Partners [1983] 1 All E.R. 65 (H.L.).

14. Sparham-Souter v. Town and Country Developments Ltd. [1976] Q.B. 858 (C.A.). For an elaboration of these points, see John Irvine, "Case Comment Kamloops v. Nielsen" (1984) 29 C.C.L.T. 185 and Bruce Feldthusen, "City of Kamloops v. Nielsen: A Comment on the Supreme Court's Modest Clarification of Colonial Tort Law”' (1985) 30 McGill L.J. 539. 
aldermen that he should not be harrassed about this matter as it would be his problem alone if anything went wrong. ${ }^{15}$ Nothing was ever done to enforce the stop work order and the majority infers strongly "that the City, with full knowledge ...., dropped the matter because one of its aldermen was involved." 16 This inference means that the city's failure to enforce the stop work order was found not to have been in good faith. The minority, however, after reading the entire record, was " unable to find any evidence which would support any such inference of impropriety on the part of the Council."' This point should, in hindsight, have been nailed down by further evidence, because the minority, while holding that there is no general duty on a municipality to enforce its by-laws, might have found for the plaintiff if the evidence had shown bad faith or corruption: "But the scanty evidence in the perhaps inadequate record before this Court would allow no such conclusion to be drawn." 18

This disagreement on the proper inferences from the facts (which in my view should be decided in favour of the majority) accounts for the otherwise strange failure of the majority even to consider its own court's holding in Welbridge Holdings Ltd. v. Winnipeg ${ }^{19}$ which was a mainstay of the minority's reasons. Apparently, all the judges in Kamloops agree that bad faith in the exercise (or in the failure to advert to the exercise) of discretion renders ultra vires the otherwise unchallengeable policy decision of a public body about by-law enforcement. The majority and the minority merely disagree on whether such bad faith is reasonably to be inferred from the facts. ${ }^{20}$

\section{VICARIOUS OR DIRECT LIABILITY?}

In order to advise municipalities how to minimize their exposure to negligence liability, it is crucial to know whether Kamloops was liable directly for its council's shortcomings or for those of the building inspector. For convenience of reference, I will call these "direct" and "vicarious". If only direct liability was involved, there is no need to amend municipal by-laws to remove any obligation on city building inspectors to enforce their by-laws. Yet this advice is presently being given by bemused municipal lawyers. For if only direct liability is involved here, surely it will be relatively easy for councils to give good faith consideration at a policy level whether or not to enforce. If they do this, the Kamloops case is not a threat.

Obviously, however, if the inspectors were at fault in the case, it was for their failure to enforce the by-law through some form of court proceeding,

15. Supran. 1 at 6-7.

16. Id. at 24.

17. Id. at 46 , per McIntyre J.

18. Id. at 60 .

19. [1971] S.C.R. 957.

20. We might note here that if the trial judge's finding of liability implies a finding of bad faith (that is, if he meant to find direct liability for the council's misconduct and not merely vicarious liability for any failure of the building inspector), the minority would have been entitled to overrule him only if there was no evidence of bad faith. With all due deference to the minority's opinion to the contrary, however, there was some evidence on which bad faith could have been inferred. 
either by laying charges or by seeking an injunction. If this is why Kamloops was liable, improving the clarity of the inspectorate's by-law enforcement mandate is of vital importance.

The minority had no problem with this question. For McIntyre and Estey JJ., the difference between a public body being liable vicariously and having an original independent liability "is of fundamental importance and goes far to distinguish the case at bar from the trilogy of cases culminating in $A n n s,{ }^{\prime 21}$ where, to them (incorrectly), only vicarious liability was in question. ${ }^{22}$ Here, the minority felt, the claim was of direct, not vicarious, liability:23

The building inspectors have fully and adequately performed their duties . . . and no vicarious liability can be visited upon the City because of any failure on their part.

McIntyre J., for the Supreme Court minority, is very clear that Lambert has erroneously done just this: ${ }^{24}$

It will be seen that Lambert J.A. has applied the principles ... in the Anns case to find a private duty upon the building inspector to prevent construction and occupation ... by seeking an injunction under the powers conferred in ss. 734 and 735 of the Municipal Act.

The majority, on the other hand, is unclear on this point. Wilson J. says that it is important to decide whether the building inspector failed to do anything which he was under a duty to do and whether this failure contributed to the plaintiff's damages. ${ }^{25}$ Unless vicarious liability was involved, it seems odd that these questions were important. Yet she immediately goes on to speculate that although this duty looks operational, there is also a policy element. The dividing line is a fine one, but Wilson seems to conclude that deciding whether to litigate to enforce the by-law was in this case a matter of policy for the city. She never explicitly says that the inspector failed to fulfill a common law duty, but instead uses the inclusive term "the city" when describing the entity which had failed to give serious consideration to enforcement. She never explicitly says that it was council's failure alone, although clearly it did fail to enforce. But so did the inspector and in the light of the B.C. Court of Appeal's holding that he had a public law duty and should have sought an injunction ${ }^{26}$ and of the ambiguity in the Supreme Court majority judgment, we can justifiably wonder just whose failure led Wilson J. to impose liability. She seems to treat the inspector and the council as the same entity. One might think that the fact that policy considerations were involved shows that the city was being held liable directly for its council's failure.

21. Supra n. 1 at 59.

22. The minority is clearly incorrect here. In Anns the statement of claim claimed in the alternative for negligent failure to inspect or for negligent inspection ([1977] 2 W.L.R. 1024 at 1030). The appeal was on a preliminary point of law so the facts had to be assumed. Therefore, Lord Wilberforce's judgment adverts both to the possibility of direct liability for the council's failure and of vicarious liability for any negligence by the inspectors (id. at 1038). Wilson J. correctly states this point (supra n. 1 at 11).

In a case comment on Kamloops, John Irvine calls this confinement of Anns to vicarious liability "as cavalier a piece of distinguishing as one will find in the books" (supra $\mathrm{n}$. 14 at 192).

23. Supra n. 1 at 48.

24. Id. at 46.

25. Id. at 21 .

26. (1981) 31 B.C.L.R. 311 at 318-19. 
Nevertheless, the point remains unclear. In her rebuttal to the "floodgates argument" against liability, Wilson J. refers to the need for the courts to avoid usurping the "proper authority of elected representatives and their officials" (emphasis added). ${ }^{27}$

To make matters even more confusing, at one point she formulates this duty in a manner consistent with the minority's conclusion that the inspector had fulfilled it: $:^{28}$

The duty of enforcement which the By-law imposed on the building inspector required him at the very least to determine the scope of the measures which were necessary to achieve that end (to prevent the construction of houses on defective foundations) and ... to attempt to obtain the approval of the City for them.

Since the inspector did issue a stop work order and did report to council regarding this matter, we are left in some doubt whether Wilson J. did accept Lambert J. A.'s vicarious liability. It is worth noting, however, that Lambert's crucial paragraph, like Wilson J.'s analysis, slid from "the inspector" to "the city" and the minority's view that he had found vicarious liability is not irrefutable.

In spite of the confusion, I conclude that the case was decided on the basis of direct liability for the council's failure, not the inspectorate's.

\section{WHAT WAS THE MUNICIPALITY'S DUTY?}

If, indeed, the majority did hold for direct liability, there is still confusion. Wilson J. quotes Lambert J. A. as to what the city should have done: 29

Policy decisions could have confronted the city as to whether to prosecute or seek an injunction. There may have been other policy choices. But a decision not to act at all, or a failure to decide to act, cannot be supported by any reasonable policy choice. That decision or failure was not "within the limits of a discretion bona fide exercised", using again the words of Lord Wilberforce.

This formulation, however, flies in the face of the Supreme Court's decision in Welbridge Holdings v. Winnipeg ${ }^{30}$ which was heavily relied on by the minority in Kamloops, although ignored by the majority.

One possible explanation is that Wilson $\mathrm{J}$. did not intend to agree with this wide a statement. Indeed, when she summarizes Lambert's position, she states it differently: ${ }^{31}$

\footnotetext{
... as I read his reasons, his view was that the city at the very least had to give serious consideration to taking the steps toward enforcement that were open to it. If it decided against taking them, say on economic grounds, then that would be a legitimate policy decision within the operational context and the courts should not interfere with it.
}

This seems a correct statement of the law. It incorporates Welbridge and is also preferable from the policy point of view. But as a rereading of Lambert's just quoted remark shows, it is not what he appears to have said. Perhaps the two judgments can be reconciled if we interpret Lambert's "decision not to act" as meaning a decision not even to consider whether to enforce, instead of the more obvious possibility of a decision not to enforce. Otherwise, we are left up in the air again.

27. Supran. 1 at 25.

28. Id. at 33 (words in brackets provided from Wilson J.'s previous sentence).

29. Id. at 22.

30. Supra n. 19.

31. Supran. 1 at 24. 


\section{VICARIOUS AND STRICT LIABILITY CANNOT CO-EXIST HERE}

It is hard to see how both direct and vicarious liability could co-exist here. If the general words in the by-law ${ }^{32}$ sufficed to delegate all the council's powers of going to court, ${ }^{33}$ council would have been powerless to tell the inspector not to go to court to enforce the by-law. In this case, council could not be directly liable - it simply had no power to act. For if delegation of court enforcement was intended, as Lambert J. A. seemed to believe, the word "shall" in the by-law must be read as a general instruction to take all persons to court if they ignore the inspector's notice of the deficiency. On the other hand, if no such enforcement powers were delegated to him, ${ }^{34}$ the city could not be liable vicariously here since the inspector had not culpably omitted to do anything. It could be directly liable only for council's own failure.

Council, which under the cases ${ }^{35}$ has the power in good faith to decide how and to what extent its by-laws should be enforced (at least when the applicable statute is merely permissive), may conceivably have meant in this case to delegate full powers to, and an obligation upon, its building inspector to enforce its building by-law in court. This is probably more likely than a delegation with discretion. But the odds are high that no such delegation was ever considered. If this is so, the minority is right to see this case as involving only direct liability of the municipality and building inspectors across the land can breath easier.

\section{THE DISTINCTION BETWEEN NON-FEASANCE AND MISFEASANCE}

In a section of her judgment entitled "non-feasance and misfeasance", Wilson $\mathbf{J}$. canvasses various cases against public authorities which discuss these concepts. Unfortunately she does so virtually without comment, except by underlining passages which have caught her eye. She begins the next section of her reasons, however, by stating that the non-feasance/ misfeasance dichotomy is irrelevant, where the inspector was under a duty to do the thing he failed to do. ${ }^{36}$ If he failed to do it, he is liable; if he did not, he is not.

32. S. 900 "The building inspector shall enforce the provisions of this by-law and administer the by-law."

33. The cases suggest that a municipality (or statutory body) does not act validly when purporting to subdelegate the very power it is given, in the very words of the original regulation or statute. This is not, however, the type of delegation here contemplated. Council set up an administrative scheme pursuant to the enabling legislation and whatever enforcement powers were delegated were in the context of the scheme created by Council. Council did not abdicate its power of legislating control over building. See, e.g., Re Peralta (1985) 49 O.R. (2d) 705 (C.A.); Brant Dairy Co. Ltd. v. Milk Commission of Ontario [1973] S.C.R. 131; Canadian Institute of Public Real Estate Companies v. City of Toronto [1979] 2 S.C.R. 2.

34. Re Resolution of Town of Melville [1953] 1 D.L.R. 208 (Sask. Dist. Ct.). The reasoning in Re Hartley and City of Toronto also assumes that a city council cannot instruct an of ficial not to carry out his or her duties under a by-law ((1925) 56 O.L.R. 433 at 434 per Hodgins J.A., upholding the judgment below (55 O.L.R. 275)).

35. See the cases cited by McIntyre J., supra n. 1 at 51-59.

36. Id. at 22. 
This, of course, begs the question, which is whether or why anyone should be under a duty to act as opposed to being liable if she does. To ignore this is to ignore a historic and morally relevant distinction which leading scholars like Smith and Burns find of prime importance. ${ }^{37}$

It should be noted, however, that other scholars applaud the rejection of the non-feasance/misfeasance distinction. ${ }^{38}$ Irvine refers to the "old sophistries" of non-feasance and misfeasance. ${ }^{39}$ Although some philosophical nonsense has no doubt been written by judges about the grey area where inaction during the course of an overall course of action may sometimes correctly be classified as misfeasance, it is submitted that the distinction between the two has a sound moral basis. Surely we should treat the Kamloops and Anns line of cases as a public authority exception to the general rule that mere inaction (not part of a more general course of action) does not render a defendant liable. We should think long and hard before imposing a general duty upon a private defendant to act to avoid foreseeable harm to another. The duty in Kamloops was derived from statute, not common law.

\section{CONCLUSION}

Kamloops' holding may not be as wide as the alarmists fear, if we take it to involve only direct liability on Wilson J.'s formulation of Lambert J. A.'s reasons instead of what he seemed to say. Municipalities are not automatically liable for foreseeable loss caused by their failure to enforce their by-laws. Rather, following Anns v. Merton London County Council,${ }^{40}$ direct, non-vicarious liability for negligence is reserved for municipalities which do not exercise in good faith their undoubted discretion as to how much effort they should put into enforcement. Welbridge lives, and liability for operational negligence continues as before. This interpretation of the case seems, on balance, to be the stronger one.

With some trepidation, I offer the following comments. Even though the result is right, some of the analysis in the Kamloops case leaves much to be desired. If the able and devoted judges on the Supreme Court are forced to decide leading cases in this fashion, we must perhaps look to reducing their workload or increasing their research assistance. Something is going wrong. The majority judgment is like a house of cards, not a wall of interlocking bricks and mortar. Lawyers should not be forced into arcane linguistic analysis when, as here, the judges could very easily clarify the basis for their judgment.

37. J.C. Smith and Peter Burns, supra n. 9.

38. Nicholas Rafferty, "Tort Liability of Public Authorities: Anns, Economic Loss and Limitation Periods"' (July/August 1985) Professional Negligence 121; John Irvine, supra n. 14; Bruce Feldthusen, supra n. 14.

39. Id. at 192.

40. Supra n. 3. 